\title{
Looking for a Success in the Euro Crisis Adjustment Programs: The Case of Portugal
}

\begin{abstract}
Portugal's economic adjustment program in 2010-14 under the troika was extensive, designed to address both its large debt and its anemic growth, so it might serve as a blueprint for reforms in the eurozone. This paper argues that, based on a diagnosis of the underlying problems of the Portuguese economy, the adjustment program failed to definitively address the public finance problems but succeeded in opening a pathway for reforms in the economy. On the negative side, public debt is still high, primary surpluses improved only modestly, and public spending barely fell as the problem of ever-rising pension payments remained unsolved. On the positive side, unemployment fell sharply, exports and the current account balance rose, capital and labor reallocated to more productive and tradable sectors, and the economy is growing faster than the European Union average for the first time in 15 years.
\end{abstract}

F rom the start, the euro crisis posed a unique challenge to crisis management. In many ways, the events of 2010-11 in Greece, Ireland, Portugal, and Spain resembled a classic sudden stop. But dealing with the ensuing recession was bound to be difficult, as there were no European institutions set up to deal with a crisis of this type and magnitude. There was no currency to devalue, no independent central bank to back up and resolve struggling national banks, and few private bondholders to arrange for a debt write-down. Large and legally protected welfare states are everywhere hard to reform, and these European countries are no exception. As a result, the adjustment programs for these four countries were partly improvised and unique in their features, and their effectiveness was in question from the start.

Still, if the euro survives, there will surely be new crises in the future. In turn, as other regions in the world choose different forms of economic integration, they would like to learn what mistakes to avoid in following 
the European example. Inspecting the adjustment programs put in place during the past few years is therefore in order.

Looking for a failed adjustment program is easy: no matter where the blame lies, it is undeniable that the Greek program has failed, with grim consequences for its population. Pointing to a successful adjustment program that could serve as a fair counterexample is more difficult. Ireland, for example, had started many of the reforms to its banking sector and public finances before its adjustment program began, and there were few macroeconomic measures in that program. Spain received financial assistance to recapitalize its banks with conditions on implementing reforms in its financial sector, but it did not enter a full-fledged macroeconomic adjustment program at the hands of the International Monetary Fund (IMF). This leaves Portugal as a potential example of success to counterbalance the failure in Greece.

Portugal is a good case to focus on for many reasons. Its adjustment program is already complete, and it consisted of an exhaustive list of reforms almost all of which were fully implemented. Coming after the interventions in Greece and Ireland, Portugal's program benefited from the accumulation of some experience. Finally, while all four countries have their idiosyncrasies, Portugal's crisis did not involve a housing price boom, nor extreme fiscal profligacy, but was mostly due to a complete lack of productivity and economic growth since 2000. Success in reversing that slump might offer lessons on how to raise the disappointing prospects for economic growth in the euro area as a whole.

There are two public views on the success of the adjustment program. One is captured by the statement of the influential German finance minister Wolfgang Schäuble, commenting in June 2014 on Portugal's announcement of the end of its program with the IMF:

Portugal's reform efforts have paid off. Today's decision by the government in Lisbon is proof of this. Portugal no longer needs European assistance and can stand on its own two feet again. This is a major success. Capital market confidence has returned, and rightly so. (German Federal Ministry of Finance 2014)

From a narrow perspective, with success defined as being able to resume sovereign borrowing, Portugal delivered. The Portuguese state became able to borrow again and at moderate 10-year interest rates, both at the end of the program (at 3.5 percent) and thereafter. Throughout 2015, average monthly 10 -year interest rates never exceeded 3 percent, despite the Greek crisis. ${ }^{1}$

1. The sources for the data mentioned in the text are varied; they are described in the online appendix. Online appendixes for all papers in this volume may be found on the Brookings Papers web page, www.brookings.edu/bpea, under "Past Editions." 
Equally important, the troika ${ }^{2}$ extended the maturity of the Portuguese official debt and reduced interest payments, and the Portuguese debt office successfully extended the maturity of the outstanding debt, with 10-year issuances throughout 2014 and 2015. As a result, the average maturity of the debt increased from 6 years in 2010 to more than 8 years at the start of 2015, reducing rollover risk (Reis 2015). Another debt crisis is unlikely in the near future.

A different view from Schäuble's was expressed one year later by Paul Krugman (2015) in an editorial that included Portugal among "Europe's Many Economic Disasters," where he stated:

Portugal has also obediently implemented harsh austerity-and is 6 percent poorer than it used to be.

From the perspective of macroeconomic performance, the program seems to be a failure, with real GDP per capita 4.9 percent lower in 2014 than it was in 2010 , and total employment falling from 4.9 million to 4.5 million. If success is judged as a rebound of the economy from its prolonged depression, then there is little to celebrate.

There is a simple way to reconcile these two opposing views. The first view focuses on public finances, where the program has delivered, while the second view argues that its consequences were a macroeconomic disaster. Both views could be right, with success in stabilizing public finances accompanied by few gains in getting the economy out of its slump. This paper argues, however, that both views are most likely wrong. Its verdict on the adjustment program is actually the opposite of the two views represented above: there are promising changes in the structure of the economy, but public finances remain far from a path that lowers the public debt.

It is hard to judge the success of a program without knowing what its criteria are and what counterfactual one is using to judge it against. My approach is to look at the progress made in solving Portugal's underlying structural problems and in addressing the four key challenges that Portugal faced at the height of the crisis: paying for large past debts, controlling future public spending, restarting economic growth and lowering unemployment, and improving competitiveness and capital allocation. I begin in section I by providing a diagnosis of Portugal's slump and crash. In sections II through V, I then measure success conditionally on the economy's

2. The "troika" is the common moniker for the trio of international institutions that have dominated financial rescue operations in Europe since the financial crisis: the European Commission, the European Central Bank, and the International Monetary Fund. 
diseases to determine whether the program helped to heal them. ${ }^{3}$ Another approach would have been to compare the adjustment program to what would have been ideal, that is, if the best policies had been followed. While there have definitely been many mistakes, I leave for others the job of highlighting them and arguing whether they are only clear now with the benefit of hindsight.

\section{Diagnosis of the Crisis}

Portugal requested international help in April 2011 and officially agreed to terms one month later. This came after a run-up in 10-year interest rates on government bonds, which reached 9.6 percent in May, up from 5.0 percent one year earlier. The government had difficulty rolling over bonds that were coming due and signed a 3-year agreement with the troika to secure financing of up to $€ 78$ billion, which expired on June 30, 2014.

The euro crisis arose when large capital flows from the core to the periphery of Europe, which had built up since the introduction of the euro, suddenly reversed in 2009-10. Without a currency to depreciate between different regions of the eurozone, the large and sudden contraction in the current account deficit required a large contraction in domestic consumption and investment, driving these economies into recession. A fall in the real exchange rate was required, but the usual rigidities that slow the adjustment of prices and wages led to a large and prolonged increase in unemployment. This is the traditional side of the crisis (Shambaugh 2012; Blanchard 2013).

New to this sudden stop, the capital flows across borders were intermediated by banks and largely funded through the interbank market (Brunnermeier and Reis 2015). In the European periphery, banks and capital markets lacked the depth to allocate the large inflows that came with financial integration, likely misallocating them into unproductive nontradable sectors. A flight to safety in response to higher risk aversion following the 2008 financial crisis had a cross-border dimension in Europe. The sudden stop came with fire sales in financial markets and falls in bank capital that led to large contractions in domestic credit.

Another novel and unique feature to the euro crisis is what has been labeled the "diabolic loop" or the "doom loop" between banks and sovereigns (Brunnermeier and others 2011; Obstfeld 2013). European banks

3. The European Commission (2014) and Jorge (2014) provide alternative evaluations, more favorable and more critical, respectively. 
held large amounts of sovereign bonds. As economic activity slowed and public deficits rose, fears about sovereign default led to falls in the prices of government bonds, large losses in banks' holdings, and further fire sales and contractions in credit, deepening the recession. Once the crisis was in motion, the diabolic loop worsened because banks would offset the sudden stop of private capital by pledging government bonds as collateral at the European Central Bank (ECB) to obtain public financing. Together with the official troika bailout programs, this implied that within a few years, most of the public debt of the countries in crisis would be held by either official creditors or domestic banks. ${ }^{4}$

As a result of these features, the Portuguese crisis combined a deep recession and a debt crisis, as in other crisis countries (Fagan and Gaspar 2007; Bento 2010; Reis 2013; Alexandre and others 2014). What, then, was special about the Portuguese crisis? To start, Portugal's recession had not begun with a crash in 2010, but rather with a slump that had been going on for 10 years before that. In the 2000-09 period, real GDP per capita had grown by only 2.9 percent and the unemployment rate had risen from 4.9 percent to 11.3 percent. The extent of the economic calamity in Greece during the crisis has been often emphasized: Greek real GDP grew cumulatively by only 1.4 percent between 2000 and 2012. But Portugal grew by the same 1.4 percent during the same period, because it was already slumping in the first 10 years of the century. In addition, Portugal did not have a housing price boom nor a significant expansion of its construction sector before the crisis. Instead, the large expansion in nontradables and consequent appreciation of the real exchange rate that came with the large capital inflows from the rest of Europe took place in the wholesale and retail sectors and in community services (education, health care, and social work).

The debt crisis in Portugal also had two distinct features relative to the other crisis countries. First, there is little evidence of public profligacy in Portugal before 2007. All of the increase in public spending is accounted for by increases in the payment of old-age pensions and unemployment benefits, and both of these systems actually became less generous during this period (Reis 2013). Moreover, taxes increased. Second, partly because of the contraction in income after 2000 without as large a contraction in consumption, private external debt was higher in Portugal than in the other euro-crisis countries: net international liabilities were already 104 percent of GDP by the end of 2010 .

4. Fonseca, Crosignani, and Faria-e-Castro (2015) document the increase in banks' holdings of Portuguese debt. 
Combining these features that were common to the euro crisis with Portugal's specific characteristics, the challenge of the adjustment program was to deal with four problems: How could one pay for the accumulated debt, public and private? How could one control public spending, especially in pensions? How could one leave the slump and restart growth? And how could one restore competitiveness by improving the allocation of resources in the economy? The next four sections assess the program through these four lenses. I leave politics out of the discussion until the conclusion because of a final Portuguese distinction in its economic and debt crisis: there was a relative political consensus around the adjustment programs. Unlike what happened in Greece and Spain, the programs were signed onto by the three major center parties, and their share of the votes in polls fell only slightly during the program without handing new or radical parties large gains.

\section{Paying Past Debts}

At the start of the program, Portugal had both large public debt and large external debt. Both the private and the public sector experienced difficulty rolling over these debts, and debt overhang was holding back new investment, so adjustment required dealing with this debt.

Concerning paying the national debt, the trade balance went from -7.6 to 0.5 percent of GDP. ${ }^{5}$ The country had not had a trade surplus since World War II, so this was no small accomplishment. At the same time, if this had been achieved through a contraction in imports, both because of a contraction in aggregate demand during the crisis and because the price of oil fell, one might worry that this improvement was temporary. Arguing against this is the fact that the ratio of exports to GDP increased from 29.9 to 39.9 percent, as well as the fact that Portugal improved its share in most of its export markets.

Turning attention to the public debt, the budget deficit improved from -11.2 to -7.2 percent of GDP. Part of this was due to the reduction in interest payments when privately held debt was rolled over into troika debt. Nevertheless, the primary surplus also improved markedly, rising from -8.2 to -2.3 percent of GDP. Much ink has been spilled on the virtues and pitfalls of austerity in a debt crisis. One interesting feature of the Portuguese situation (and the euro crisis) is represented in table 1. Aside from the primary surplus since 2010 , the table also shows its projected

5. All comparisons are between 2010 and 2014, using annual data, unless stated otherwise. 
Table 1. Public Primary Deficits: Actual and IMF Forecasts

\begin{tabular}{lcccc} 
& & \multicolumn{3}{c}{ Forecasts } \\
\cline { 3 - 5 } Year & Actual & June 2011 & October 2012 & January 2013 \\
\hline 2005 & -3.6 & & & \\
2006 & -1.6 & & & \\
2007 & -0.1 & & & \\
2008 & -0.7 & & & \\
2010 & -8.2 & -1.7 & 0.2 & -0.2 \\
2011 & -3.1 & 0.3 & 2.4 & 2.1 \\
2012 & -0.8 & 2.1 & & \\
2013 & 0.0 & 2.8 & & \\
2014 & 2.3 & & & \\
\hline
\end{tabular}

Sources: IMF reports on Portugal for the years given above.

path according to different waves of IMF programs, as well as the fall in the deficit between 2005 and 2008, when Portugal was in violation of the Maastricht limits and had to bring its deficit in line. The pace of austerity was milder than what had been planned, with constantly relaxed targets, and it was similar in 2011-14 to what it had been in 2005-08. It is hard to make the case that there was unexpected austerity from the start of 2012 onwards, or to see a dramatic reform in Portuguese public finances. Another jarring comparison is that made with the United States. Between 2010 and 2014, the U.S. federal surplus improved by 5.9 percent, in spite of little talk of excessive austerity and no troika impositions; Portugal's surplus improved by only 4.0 percent.

Lowering the debt can also be done by selling assets or by restructuring liabilities. A sign of the first activity is evident in Portugal's gross external debt, which grew by only $€ 0.5$ billion, while its net international investment position worsened by only $€ 8.3$ billion. Large companies, both public and privately owned, were sold to foreigners, including the major electrical utility, the larger telecommunications company, the airline, and large banks.

As for the second, in spite of the cut in the public deficit, the stock of public debt went from 96 percent to 130 percent of GDP. This number may be misleading because it refers to the face value of the debt. However, in 2012, the troika restructured the debt of Portugal (together with that of Greece and Ireland), extending maturities and lowering interest payments, thereby reducing its market value in spite of making no cuts to the face value. Since a large share of the debt is owed to the troika institutions and is not traded, there is no market value to assess. Following Daniel Dias, Christine Richmond, and Mark Wright (2014) and Julian Schumacher and 
Beatrice Weder di Mauro (2015), I calculate the present value of the payments that the Portuguese government has committed to make to all of the holders of its debt, both private and public. If, following these authors, one uses a subjective interest rate of 5 percent per year to discount the payments, then the market value of the debt is 80 percent of its face value. If instead one uses the market discount rates for the yield curve on Portuguese debt, its market value is 95 percent of its face value.

Either way, Portugal still has a high public debt outstanding and a meager primary surplus. It is difficult to see how Portugal can get public debt under control without a new reconfiguration of maturities and interest payments on the troika debt that more significantly reduces the market value of the public debt. The radicalization of European public opinion caused by the 2015 Greek crisis has made this harder to achieve.

\section{Getting Public Spending under Control}

A large part of the reduction in the public deficit was achieved by increasing the tax rates on personal income and sales as well as tighter enforcement. Overall government revenue increased from 40.6 to 44.5 percent of GDP. At the same time, government consumption purchases fell from 20.7 to 18.5 percent of GDP, and the cut in public investment was even sharper, from 5.3 to 2.0 percent.

Nevertheless, transfers increased from 22.1 to 23.2 percent of GDP, despite all the increase in public spending between 2000 and 2007 already being entirely accounted for by increases in old-age pension payments. As a result, while total public spending fell from $€ 93$ billion to $€ 90$ billion, spending excluding public investment actually rose from $€ 84$ billion to $€ 86$ billion. Once public investment returns to its precrisis levels, public spending will be almost unchanged, mostly because of the increase in social transfers.

It is up for debate whether public spending should keep on increasing, accompanied by even higher taxes. It is more clear that given current trends, the pension system in Portugal will accumulate ever larger deficits and, absent reform, be responsible for any future fiscal crises. During the adjustment programs, the retirement age increased to 66 years, early retirement was suspended, and survivor pensions became means-tested, but most reforms were either modest or generously grandfathered. The more meaningful impact on spending came from an across-the-board cut in pensions. But these cuts were partly reversed by the constitutional court, and 
all the political parties have promised to fully reverse them in the next two years. As a result, a permanent adjustment to public spending is a task that mostly remains to be done.

\section{Making Structural Reforms: Growth and Labor Markets}

Between 2000 and 2009, Portugal's real GDP per capita grew 7.3 percent less than the European Union average, excluding Germany. By the end of the adjustment program, in 2014, Portugal was growing 0.3 percent faster than the European Union, excluding Germany, and the IMF forecasts that it will continue doing so in the near future. Since 2000, Germany has been unusual in comparison with the rest of the European Union slumping in the beginning of the century and booming after 2010 when the rest of Europe was in crisis. Treating the European Union, excluding Germany, as the appropriate comparison, growth seems to have resumed in Portugal, starting the process of catching up to the rest of Europe.

In this comparison, it is important to note that the economic outlook is still dismal. Growth forecasts from the IMF for the next 3 years are a modest average of 1.5 percent per year, reflecting the economic stagnation of the European Union. But from the perspective of the adjustment program, it is a good sign that Portugal has resumed convergence with the rest of Europe after diverging since the start of the century.

Moreover, unlike in other European labor markets, Portuguese unemployment has fallen quite rapidly so far. The seasonally adjusted unemployment rate at the end of 2014 was 13.6 percent, still above the value at the end of 2010 (12.2 percent), but it fell to 12.2 percent by September 2015 after falling almost monotonically from its peak of 17.5 percent in January 2013.

Why this quick adjustment? One distinguishing feature of the Portuguese labor market is its dual nature (Centeno and Novo 2012). On the one hand, many workers benefit from protected contracts that make layoffs expensive, contribute to low job creation and destruction, and encourage low labor productivity. On the other hand, as many as half of all workers are on term contracts and switch jobs often. These include the large majority of jobs created in this century and are mostly held by people younger than 40 . This duality is a development problem, since it lowers average productivity and makes reforms difficult. A large share of the population is unproductive and almost impossible to fire. Yet, at the margin, it implies that the Portuguese labor market is actually somewhat flexible. Because the marginal 
worker is in a term contract, job creation and destruction are easy, and the unemployment rate can adjust quickly to major macroeconomic shocks. ${ }^{6}$

This duality also suggests that evaluating the adjustment in the labor market requires looking at the composition of employment. This will let us see whether churn in the labor market during the adjustment programs affected the average worker and average productivity in the economy. Total employment fell from 4.867 million to 4.492 million workers, although looking across sectors one finds that agriculture and construction, combined, account for two-thirds of this reduction. Looking at education levels, employment of workers with a primary school education or less declined by 824,000 , so employment among those with secondary schooling or higher education actually increased during these four years of crisis, by 192,000 and 293,000, respectively.

Another sign of this compositional adjustment comes from the adjustment of labor compensation. Wages fell the most (by 8 percent) for those with higher education, while they fell only slightly (by 1 percent) for those with primary education or less. At the relevant margin of adjustment, wages adjusted flexibly, and employment rebounded. In aggregate, real unit labor costs fell by 6.6 percent during these four years, mostly due to a fall (5.3 percent) in real compensation.

These numbers suggest structural changes in the Portuguese economy and, perhaps, a reversal of the misallocation of resources that had plagued it for the past 15 years.

\section{Competitiveness and the Allocation of Capital}

In the World Economic Forum's global competitiveness index, Portugal improved in its ranking from 46th to 36th between the 2010-11 report and the 2014-15 report (Schwab 2010, 2014). This was the result of many legal reforms that were part of the extensive adjustment programs. The IMF (2015b) documents 494 different structural reform actions, about half of them in the public sector and half in the deregulation of product, labor, and financial markets. Whether any of them leads to higher economic growth is an open question.

6. Some of the decline in unemployment was certainly also due to emigration: the population fell by 172,000 , or 1.6 percent. This decline in population has been steady since 2010 , though, while unemployment rises and falls. A third driver of the fall in unemployment is decline in participation by the discouraged long-term unemployed, but careful statistical work to quantify how large this population was remains to be done. 
Competitiveness is often measured using a real exchange rate. Yet the movements in the Portuguese effective real exchange rate were mostly due to changes in the value of the euro against other currencies. Most of the capital flows happened within European Union borders, toward nontradable sectors in the periphery, and to less productive and more protected industries (Reis 2013). A more appropriate diagnosis of competitiveness than the real exchange rate is the relative price of nontradables. Between 2010 and 2014, that price fell by only 2.4 percent, signaling little improvement.

At the same time, as noted already, exports and the tradable sector expanded considerably. The current account surplus went from -10.1 to 0.6 percent of GDP, suggesting a marked improvement in competitiveness. Much as in the years before the crisis, there was a significant reallocation across tradables and nontradables during the adjustment in spite of small changes in relative prices.

To find signs of an improved allocation of resources, it would be desirable to have estimates of productivity and markups. Neither type of estimate is available with current data. However, a much more imperfect measure of labor productivity — output per hour-is available: it increased by 2.8 percent in the overall economy. More interestingly, Reis (2013) emphasizes that two sectors - retail and wholesale trade and real estate activities-had a large increase in markups and stagnant productivity in 2000-07 and yet absorbed large amounts of the capital inflow. These two sectors had among the largest increases in output per hour between 2010 and 2014-11.1 percent in wholesale and retail trade and 10.8 percent in real estate-even as they shrank in their relative size. This evolution is consistent with misallocation and inefficiency before the crisis and with an improvement during the adjustment program.

As is typical in Europe, the financial system is dominated by banks, which are crucial in allocating capital across sectors. Since 2010, the shareholders of most banks in Portugal lost almost all their investment after several waves of recapitalization, with one of the four major banks going through resolution. Moreover, the banks were subject to the ECB's asset quality reviews as well as more intense regulation. The fall in total loans is more than fully accounted for by the decline in loans to the construction sector, and the ratio of credit to deposits increased.

There are reasons to be wary of the state of banks' finances. First, nonperforming loans to nonfinancial corporations have increased almost continuously, from 4 to 14 percent. Rather than rising sharply at the start of the adjustment program as banks and regulators revalued assets, this slow 
and prolonged acknowledgment of losses suggests that banks may have been rolling over bad loans. Second, and confirming this fear, corporate debt stayed almost unchanged at 153 percent of GDP. By comparison, in Spain during the same period, corporate debt fell by more than 20 percent of GDP. The IMF (2015a) partly attributed this absence of deleveraging in Portugal to the lack of legal reforms allowing for corporate bankruptcies and debt write-downs.

\section{Conclusions}

It is difficult to call an adjustment process a success when the country in question has barely grown in 15 years and unemployment is 12.2 percent, yet the Portuguese economy has changed in many directions that seem promising. The misallocation of resources that plagued it seems to have started to reverse, as export sectors have grown, employment has shifted to more educated workers, the protection of local interests has declined, and output per hour has increased in the least productive sectors. The economy is growing faster than in the rest of Europe. While the definitive tests of adjustment will be whether economic growth in the next few years is able to offset the stagnation of the last 15 years, there are encouraging signs of success.

At the same time, it is easy to claim success in adjusting public finances when looking at the profile of stable and small payments that the Portuguese state has to make in the near term. However, behind the low interest rates and longer maturities, public debt is 130 percent of GDP, austerity was far from being decisive in generating large primary surpluses, and public spending will keep on rising given the lack of pension system reform. The evolution of public finances is closer to being a failure than a success, and without a quiet restructuring of the debt to the European authorities over the next few years that could lower its market value, there are reasons to be worried.

In the near term, as the recent Greek crisis illustrates, it is often politics that derails adjustment. In this regard, the troika has found a very committed and cooperative government in Portugal during the last four years. At the same time the troika insisted on changes in pensions, which have repeatedly been deemed unconstitutional by the courts, it pushed for changes to the structure of payroll taxes that were very unpopular, and it sent contradictory public messages on the need to adjust public finances. Starting from an initial position of support for reforms, the troika made 
itself unpopular, often unnecessarily. Even if there is no dramatic reversal of the reforms so far, it is uncertain whether what remains to be done will ever take place.

ACKNOWLEDGMENTS I am grateful to the editors for discussions and encouragement, to Kevin O'Rourke for his discussion, and to Cynthia Balloch for research assistance. 


\section{References}

Alexandre, Fernando, Pedro Bação, Pedro Lains, Manuel M.F. Martins, and others, editors. 2014. A Economia Portuguesa na União Europeia [The Portuguese Economy in the European Union]: 1986-2010. Lisbon: Actual Editora.

Bento, Vitor. 2010. O Nó Cego da Economia: Como Resolver o Principal Bloqueio do Crescimento Económico [The Blind Knot of the Economy: How to Solve the Main Blockage of Economic Growth]. Lisbon: Bnomics.

Blanchard, Olivier. 2013. Comment to "The Portuguese Slump and Crash and the Euro Crisis." Brookings Papers on Economic Activity, Spring: 194-97.

Brunnermeier, Markus K., Luis Garicano, Phillip R. Lane, Marco Pagano, and others. 2011. "European Safe Bonds (ESBies)." http://www.columbia.edu/ rr2572/ papers/11-ESBies.pdf

Brunnermeier, Markus K., and Ricardo Reis. 2015. "A Crash Course on the Euro Crisis." Presentation. http://scholar.princeton.edu/sites/default/files/01b\%20 EuroCrashCourse_slides_0.pdf

Centeno, Mário, and Alvaro A. Novo. 2012. "Segmentation.” Economic Bulletin [Banco de Portugal] 18, no. 1: 7-27.

Dias, Daniel A., Christine Richmond, and Mark L. J. Wright. 2014. "The Stock of External Sovereign Debt: Can We Take the Data at 'Face Value'?" Journal of International Economics 94, no. 1: 1-17.

European Commission. 2014. "The Economic Adjustment Programme for Portugal 2011-2014.” Occasional Paper no. 202. Brussels.

Fagan, Gabriel, and Vitor Gaspar. 2007. "Adjusting to the Euro.” Working Paper no. 716. European Central Bank.

Fonseca, Luís, Matteo Crosignani, and Miguel Faria-e-Castro. 2015. "Central Bank Interventions, Demand for Collateral, and Sovereign Borrowing Costs." Working Paper no. 9. Banco de Portugal.

German Federal Ministry of Finance. 2014. "Portugal Exits IMF-EU Programme/ Finance Minister Schäuble Welcomes Decision.” http://www.bundesfinanzmin isterium.de/Content/EN/Standardartikel/Topics/Europe/Articles/2014-06-12portugal-exits-imf-eu-programme.html

IMF (International Monetary Fund). 2015a. "Portugal: First Post-Program Monitoring Discussions-Staff Report; Press Release; and Statement by Executive Director.” IMF Country Report no. 15/21. Washington.

—. 2015b. "Portugal: Selected Issues." IMF Country Report no. 15/127. Washington.

Jorge, Rui Peres. 2014. Os 10 erros da Troika em Portugal: Austeridade, Sacrifícios e Empobrecimento; as Reformas que Abalaram o País [The 10 Mistakes of the Troika in Portugal: Austerity, Sacrifices, and Impoverishment; Reforms That Shook the Country]. Lisbon: A Esfera dos Livros.

Krugman, Paul. 2015. "Europe's Many Economic Disasters.” Op-ed. New York Times, July 3.

Obstfeld, Maurice. 2013. "Finance at Center Stage: Some Lessons of the Euro Crisis." Economic Paper no. 493. Brussels: European Commission. 
Reis, Ricardo. 2013. "The Portuguese Slump and Crash and the Euro Crisis." Brookings Papers on Economic Activity, Spring: 143-93.

2015. "Gerir a Dívida Pública" [Managing Public Debt]. In Afirmar o Futuro: Políticas Públicas para Portugal [Affirm the Future: Public Policies for Portugal], edited by Paulo Trigo Pereira and Viriato Soromenho Marques. Lisbon: Fundação Calouste Gulbenkian.

Schumacher, Julian, and Beatrice Weder di Mauro. 2015. "Greek Debt Sustainability and Official Crisis Lending." In present volume of Brookings Papers on Economic Activity.

Schwab, Klaus. 2010. “The Global Competitiveness Report 2010-2011.” Geneva: World Economic Forum.

2014. "The Global Competitiveness Report 2014-2015.” Geneva: World Economic Forum.

Shambaugh, Jay. 2012. “The Euro's Three Crises.” Brookings Papers on Economic Activity, Spring: 157-211. 


\section{Comments and Discussion}

\section{COMMENT BY}

KEVIN H. O'ROURKE Portugal burst into the news recently, following the October 4, 2015, legislative election, and the postelection maneuverings that ensued. Up until then, however, it had been the forgotten country of the eurozone crisis. Portugal's Great Recession lacks the dramatic tragedy of its Greek counterpart, or the feel-good factor of the Irish recovery. It provides less obvious arguments, both to those who support the current troika-enforced policy mix in the eurozone periphery (if only the Greeks were more like the Irish, their economy would be in better shape) and to those who condemn it (the decline in Greek GDP since 2008 has been Great Depression-sized, while even in Ireland the post-2008 experience was traumatic). And so we have tended to ignore Portugal, which is probably a mistake.

The root cause of Portugal's ejection from international capital markets, and subsequent entry into a bailout program, was slow economic growth over many years. Between 1999 (when the euro was introduced) and 2008, Portuguese GDP per capita grew by just 9.4 percent, or 1 percent per annum. This is unlike the experience in the other crisis countries: Over the same period, per capita GDP grew by 31 percent in Ireland, 33 percent in Greece, and 19 percent in Spain. Portugal's postcrisis downturn was also much less exciting than elsewhere in the periphery. Greece's per capita GDP in 2014 was just 75 percent of its 2008 level; the comparable figures for Spain and Ireland are 92 percent and 101 percent respectively. By contrast, the figure is 94 percent in Portugal, neither as bad as in the basket cases, nor as "good" as in Ireland. In short, Portugal is a bit boring. ${ }^{1}$

1. Here and elsewhere, per capita GDP data are taken from the AMECO database (http:// ec.europa.eu/economy_finance/db_indicators/ameco/index_en.htm), series RVGDP. 
But this is precisely why we should pay more attention to the country. Greece and Ireland are both sui generis: on the one side, a corrupt and fiscally profligate government; on the other, one of the biggest housing bubbles and busts in history. In contrast, Portugal's ploddingly slow growth is much more akin to what other eurozone economies have experienced, albeit without falling into bailout programs. In France, per capita GDP rose by 11 percent between 1999 and 2008, while in Italy it rose by just 7 percent (or by three quarters of a percentage point per annum). The Portuguese experience falls squarely within this range, making it a fairly canonical example of an underperforming eurozone economy. Its misfortune, perhaps, was that it fell into difficulties while Jean-Claude Trichet rather than Mario Draghi was at the helm of the European Central Bank in Frankfurt (or, perhaps, that it was not viewed as sufficiently important to trigger a "whatever it takes" declaration, unlike Spain and Italy). ${ }^{2}$

Ricardo Reis's paper provides an admirably nuanced account of Portugal's performance since the troika took over in 2011. He argues that while the fiscal problems that plagued the country in the run-up to the crisis, due essentially to a combination of slow growth and rising entitlement spending, persist, valuable progress has been made in rebalancing the real economy. If the root cause of the problem was slow growth, however, restoring growth would seem to be key to resolving it, and Reis acknowledges that "the economic outlook is still dismal." He draws comfort, however, from the fact that Portuguese growth is now faster than the European Union (EU) average, once Germany has been removed from the equation, suggesting that convergence has finally resumed.

Reis's paper is looking for a eurozone success story. Unfortunately, if you are looking for success in the eurozone you are looking in the wrong place. My figure 1 plots per capita and aggregate GDP from 2001 to 2014 for the United States, United Kingdom, European Union, eurozone, Germany, Japan, and Portugal. For the sake of consistency over time, I look at just the original 12 eurozone members, including Greece, which joined in 2001. I also plot the data for the eurozone thus defined, minus Germany, following Athanasios Orphanides (2015). The figure makes it clear how utterly woeful Europe's performance has been since the crisis. In per capita terms, neither the EU nor the eurozone had recovered to the precrisis peak by 2014, in stark contrast with the United States (whose recovery is usually viewed as disappointing by Americans) and Japan. In aggregate terms, GDP in the EU only just recovered to its precrisis level in 2014, while

2. Very high levels of private indebtedness may also have played a role. 
Figure 1. GDP and GDP per Capita, 2001-14

\section{GDP}

Log scale, $2008=100$

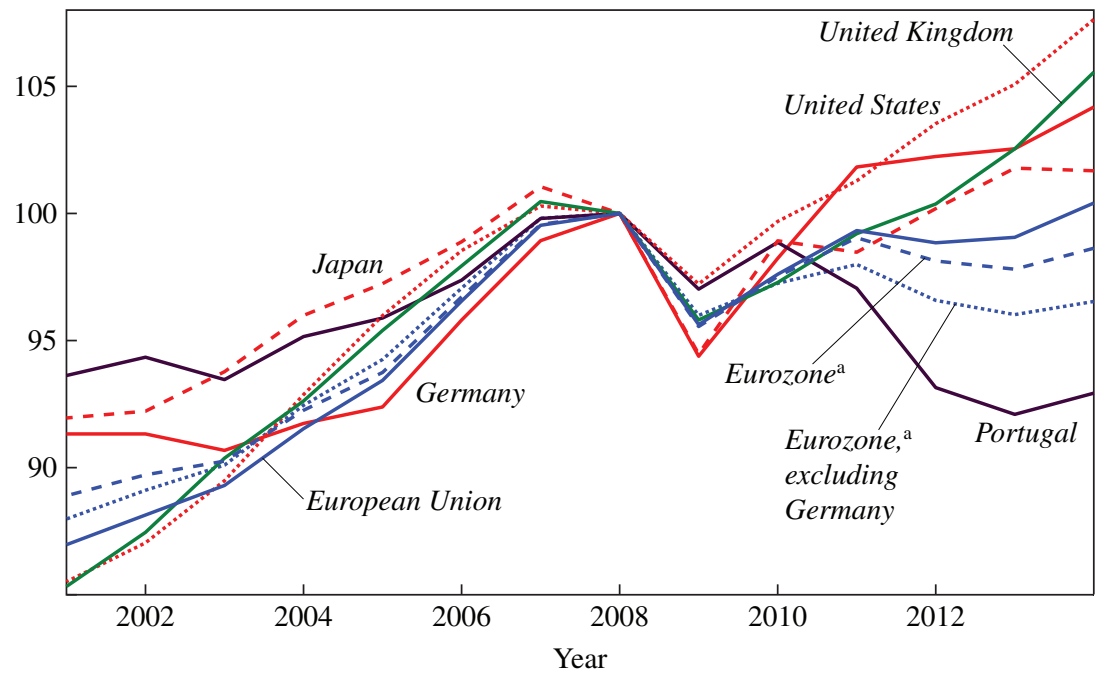

\section{GDP per capita}

Log scale, $2008=100$

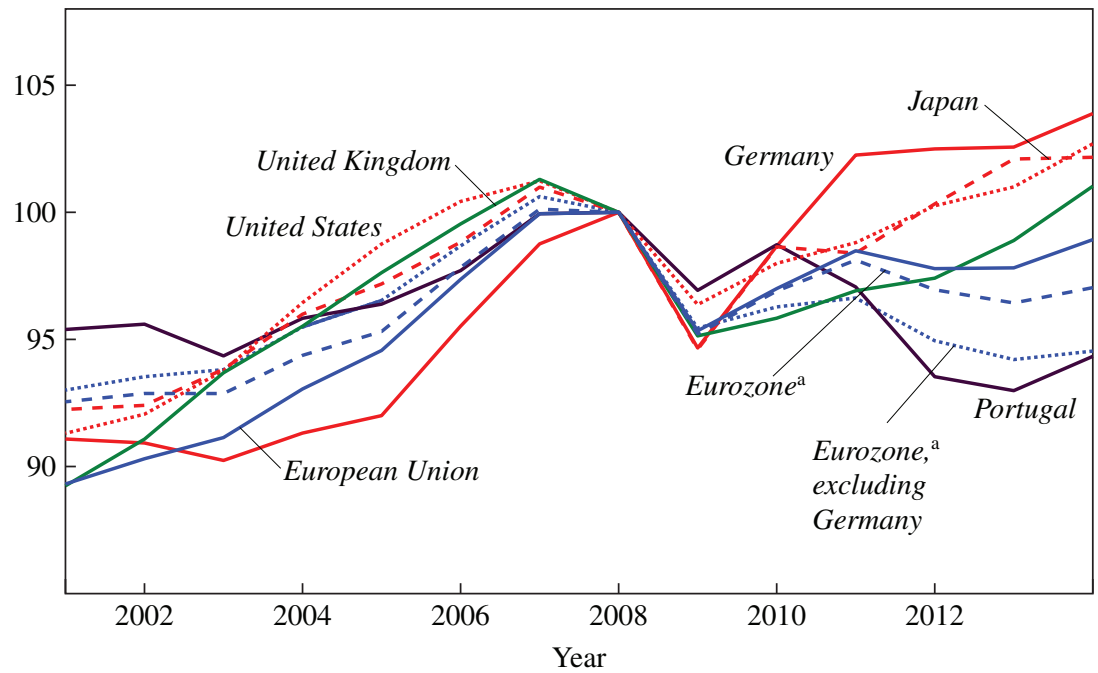

Source: European Commission, AMECO database, series RVGDP, OVGD, and NPTD (http://ec.europa.eu/ economy_finance/db_indicators/ameco/index_en.htm).

a. Refers to the 12 original member states of the eurozone: Austria, Belgium, Finland, France, Germany, Greece, Ireland, Italy, Luxembourg, the Netherlands, Portugal, and Spain. 
eurozone GDP remained 1.4 percent below it (and U.S. GDP was 7.6 percent above).

My figure 1 shows that it does indeed make sense to distinguish between the performances of Germany and the rest of the eurozone. In per capita terms, Germany's recovery has surpassed that of the United Kingdom, and even the United States; per capita GDP was almost 4 percent higher in 2014 than in 2008. In the 12 original eurozone member states, 2014 per capita GDP was almost 3 percent lower than in 2008; excluding Germany, it was 5.5 percent lower. Strikingly, Portugal's per capita GDP is now about the same, relative to the precrisis peak, as in the rest of the non-German eurozone. This is due to the more rapid growth in 2014 alluded to in Reis's paper, and is clearly visible in the graph. Whether this improvement in Portugal's relative performance is more a reflection of Portuguese success or eurozone failure is another matter. For my part, I look at my figure 1 and see a European performance that is truly dismal.

Also worth mentioning is the fact that Portugal's relative performance is a lot less impressive when expressed in terms of aggregate rather than per capita GDP. This discrepancy is in part due to emigration, which as Reis notes has led to Portugal's population falling since 2010. Conversely, emigration has presumably played a role in keeping a lid on Portuguese unemployment. In 2012 the International Monetary Fund (IMF) calculated that Ireland's unemployment rate would have exceeded 20 percent had it not been for the emigration safety valve, and it would be interesting to see a similar calculation performed for the Portuguese case (IMF 2012, p. 5).

In summary, it is hard to feel much optimism regarding Portugal's recent growth experience, and its growth prospects are not that great either. Kieran McQuinn and Karl Wheland (2015) estimate that the eurozone will grow at 0.6 percent per annum between 2014 and 2023, and at 0.25 percent or less for the subsequent 20 years. Converging on such a laggard is nothing to be happy about: They estimate that Portugal will grow at just 0.81 percent per annum between 2014 and 2023, at 0.08 percent per annum between 2024 and 2033, and at -0.32 percent per annum between 2034 and 2043. If they are right, then Portugal's fundamental problem, and the root cause of the 2011 bailout, is far from being solved.

If Portugal does not offer clear evidence of a troika success, what about Ireland? While no one should believe Ireland's GDP (or even GNP) data (FitzGerald 2013), there has been impressive growth in the country since 2013, as evidenced in rising employment numbers. But this should not be taken as evidence that the troika's intervention in Ireland "worked," or 
Figure 2. General Government Structural Balances, 2000-2014

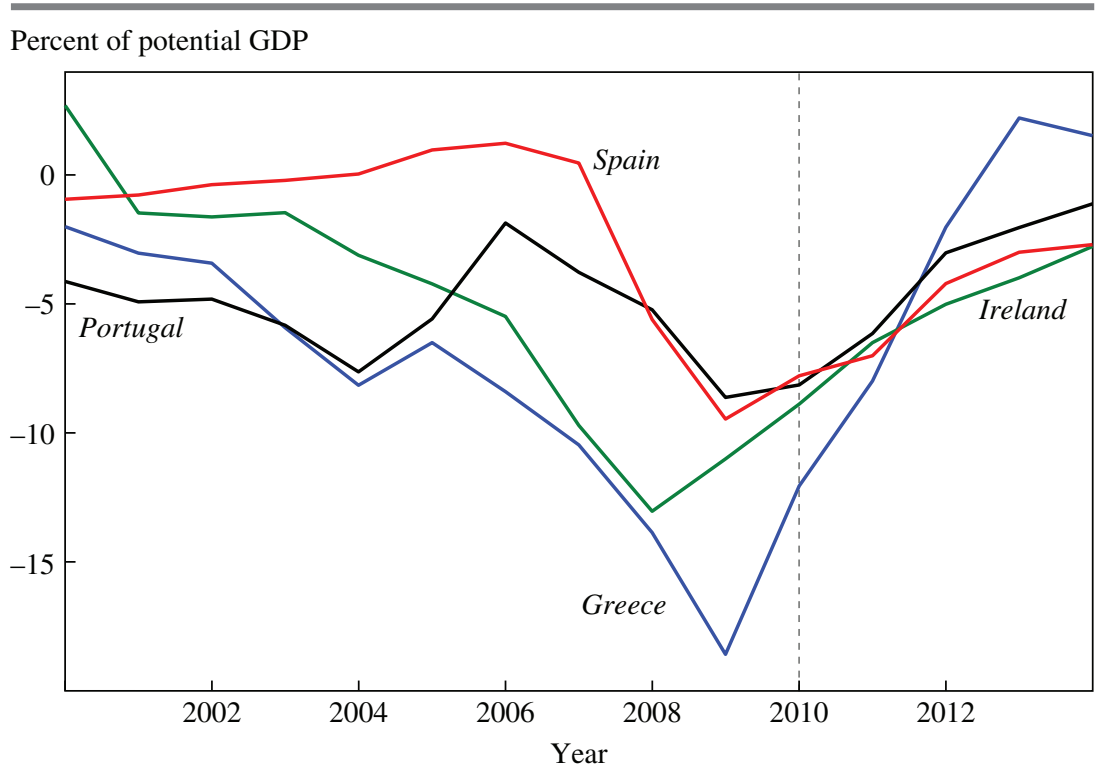

Source: International Monetary Fund, World Economic Outlook Database (http://www.imf.org/external/pubs/ $\mathrm{ft} /$ weo/2015/01/weodata/index.aspx).

a. The structural budget position is defined as the actual budget deficit (or surplus) less the effects of cyclical deviations of output from potential output.

that its medicine, if taken enthusiastically, will produce similar recoveries elsewhere in the eurozone.

Ireland's fiscal consolidation, while impressive, preceded the troika's arrival in the autumn of 2010 (my figure 2), so it is hard to either credit or blame the troika for Irish austerity. More importantly, perhaps, it is not surprising that there was political buy-in for an austerity program that was decided domestically, rather than being imposed from abroad. Another factor that must have helped in getting austerity through the political system was that Irish incomes were so high to begin with; on the eve of the crisis, per capita GDP was more than twice as high in Ireland as in Portugal, and almost twice as high as in Greece. Even subtracting 20 percent from the Irish numbers, to account for the distinction between GDP and GNP, does not eliminate the reality that Ireland is a very rich country. This surely made it easier to cut people's incomes.

My figure 2 shows that Ireland suffered considerably less austerity than Greece (but more than Portugal). Ireland is also a much more open economy than any of the other crisis countries (my figure 3), and is famously 
Figure 3. Exports as a Percent of GDP, 2000-14

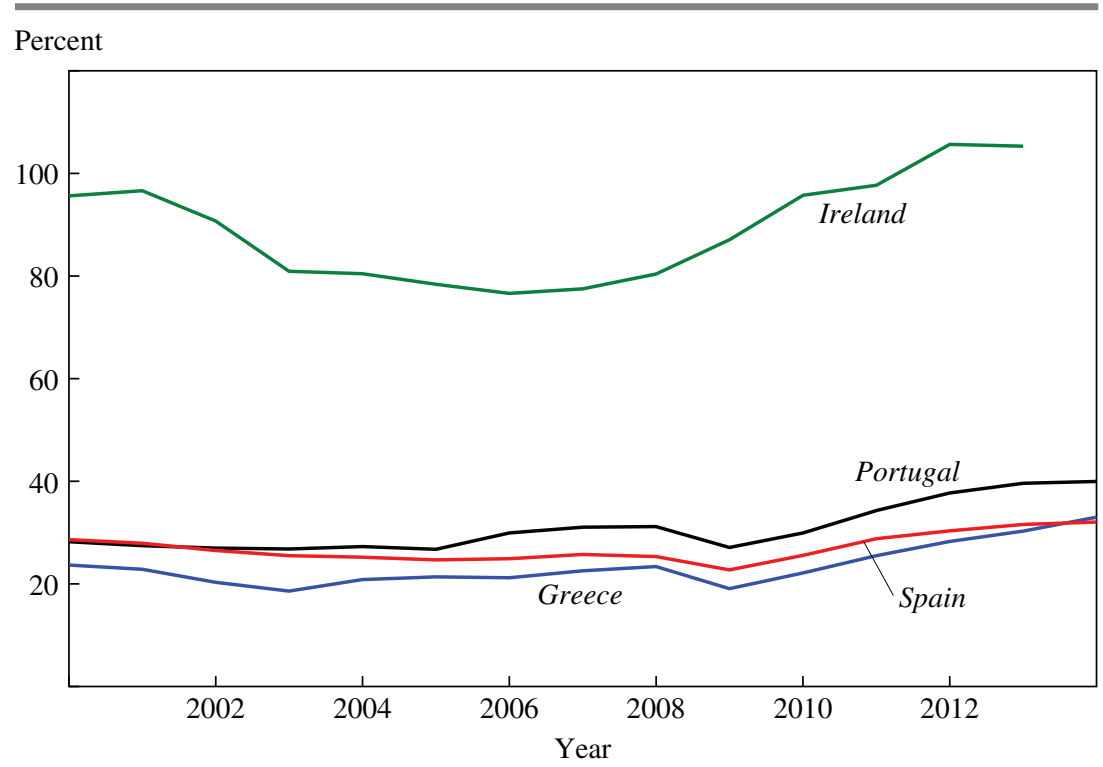

Source: World Bank, World Development Indicators.

dependent on inward foreign direct investment. This surely implies lower multipliers in Ireland than in either Greece or Portugal. Ireland also benefited from the fact that its major trading partners, the United Kingdom and United States, were outside the eurozone. This should have been a good reason for Ireland to stay outside the euro, but ironically enough it turned out to be a saving grace when the crisis hit. As my figure 1 showed, those countries' postcrisis performances, while disappointing, were streets ahead of the eurozone's. Ireland was therefore exporting into growing markets, and also benefited more than other crisis countries from the euro's depreciation in 2014 and 2015. Between January 2014 and July 2015, Ireland experienced an 8.7 percent nominal (trade-weighted) depreciation. The equivalent figures in Greece, Spain, and Portugal were 4.3 percent, 4.5 percent, and just 2.9 percent. Nominal depreciations translated into real depreciations: in Ireland's case, 9.2 percent, as opposed to an impressive 7.8 percent in Greece, 6 percent in Spain, and 2.7 percent in Portugal. ${ }^{3}$ Not surprisingly, 2014 was when Irish growth really picked

3. Source: Bank for International Settlements' effective exchange rate indexes (http:// www.bis.org/statistics/eer.htm). 
up. Interestingly enough, in percentage terms Portugal's exports have been growing at rates roughly comparable to Ireland's, the difference being that a given percentage increase in exports will have a bigger impact if exports are around 100 percent of GDP than if they are less than 40 percent. But Portuguese export growth remains impressive, not least because the country benefited from smaller nominal and real depreciations than other crisis countries. The apparently high price elasticities that this seems to imply, and that Reis alludes to in his paper, are interesting and seem worthy of further study.

Was the Irish success story due to the growth-promoting effects of troika-inspired structural reforms? It seems unlikely. True, Ireland's record when it came to implementing structural reforms was better than either Greece's or Portugal's; "close to perfect" is how Alessio Terzi (2015, p. 5) describes it. Conversely, the same author shows that the number of reforms that Ireland implemented was much lower than in Portugal or Greece, and that Ireland's reform efforts overwhelmingly involved the country's financial sector, rather than politically difficult areas such as pensions or labor market reforms (Terzi 2015, p. 4). Given that Ireland entered the crisis with a relatively flexible economy, there were fewer growthpromoting structural reforms that could be implemented there, making it difficult to attribute Ireland's recovery to the implementation of such reforms. $^{4}$

To summarize: Austerity in Ireland was home-grown; it was less extreme than in Greece; and its impact was lower because of Ireland's high incomes, its extreme openness, and the emigration safety valve. Structural reforms probably did not boost growth much if at all, but Ireland got lucky, benefiting from growing trade partners and a depreciating currency. Its economy has been growing rapidly for two years. Despite all these advantages, the Irish political landscape has been turned on its head. In the 2011 general election, the three main parties (Fianna Fáil, Fine Gael, and Labour) obtained 73 percent of the vote, down from 79 percent in 2007. They are now standing at around 57 percent in the polls, following

4. McQuinn and Whelan (2015) try to derive an upper bound estimate of the impact of pension, labor market, and regulatory reforms on European growth, assuming inter alia that regulatory reforms would raise total factor productivity to U.K. levels by 2043 . Even on this heroic assumption, structural reforms would only add 0.85 percentage point to eurozone growth between 2014 and 2043, implying growth of 1.2 percent per annum. Interestingly, they estimate that the same reforms would add as much as 1.58 percent per annum to Portuguese growth between 2014 and 2043, yielding an average growth rate of 1.81 percent per annum. 
a big swing toward Sinn Féin and an assortment of mainly left-wing protest candidates. ${ }^{5}$ European policymakers might want to think twice before imposing such a policy mix on larger, more closed economies without Ireland's enviable history of political stability.

\section{REFERENCES FOR THE O'ROURKE COMMENT}

FitzGerald, John. 2013. "The Effect of Redomiciled Plcs on GNP and the Irish Balance of Payments." Research Note no. 2013/1/2. In Quarterly Economic Commentary, Spring, by David Duffy and Kevin Timoney. Dublin: Economic and Social Research Institute.

IMF (International Monetary Fund). 2012. "Ireland: Eighth Review under the Extended Arrangement; Staff Report; Staff Supplements; and Press Release on the Executive Board Discussion." Country Report no. 12/336. Washington.

McQuinn, Kieran, and Karl Whelan. 2015. "Europe's Long-Term Growth Prospects: With and Without Structural Reforms." Working Paper no. 15/08. Dublin: University College Dublin, Centre for Economic Research.

Orphanides, Athanasios. 2015. "The Euro Area Crisis Five Years after the Original Sin.” Working Paper no. 5147-15. Cambridge, Mass.: Massachusetts Institute of Technology, Sloan School of Management.

Terzi, Alessio. 2015. "Reform Momentum and Its Impact on Greek Growth." Policy Contribution no. 2015/12. Brussels: Bruegel.

GENERAL DISCUSSION Beatrice Weder di Mauro opened the discussion by noting that Ricardo Reis seemed more optimistic about Portugal's success in his conference presentation of the paper than in the paper itself. Portugal's recovery story is certainly different from that of Greece or Ireland, but whether one should call it a success depends on the criteria, most of all on what one is comparing it to. The paper treats growth in the euro area, minus Germany, as the counterfactual, but that did not strike Weder di Mauro as the most meaningful comparison. It would make more sense to compare Portugal's experience with that of other countries undergoing IMF-type programs, making use of the kind of evaluations the IMF does periodically when adjustment programs are put into place.

Steve Davis had three questions. First, how bad is Portugal's pension reform problem-that is, what is the projected path for pensions as a percentage of GDP without reform? Second, what has happened in the

5. Recovery does seem to be helping the centrist parties; the figure is up from just 46 percent in December 2014. See http://www.oireachtas.ie/parliament and http://www. redcresearch.ie/election-2016. 
retail and wholesale sectors to facilitate the country's recent productivity improvements? And third, can the labor-productivity measures for Portugal be trusted? Davis's concern on this last point was that the output and labor input measures in Portugal, particularly in retail, are differently sensitive to unreported activity, and unreported labor inputs are easier to disguise than sales numbers. If hiring has been occurring off the books, and especially if such activity increases or decreases, that will distort the evolution over time of labor-productivity measures.

Robert Gordon wondered why Reis's paper only showed ratios to GDP when measuring whether transfers went up or down, pension costs went up or down, and the same for expenditures and exports. After all, GDP in Portugal has fallen. Would it not be more useful to measure ratios to potential output or to previous peak output, so that one could see whether these things had gone up or down in absolute terms instead of relative to a shrinking total?

Yannis Ioannides wondered about the profile of Portugal's payment obligations. In the paper, Reis predicted that without a quiet restructuring of its debts to the European authorities over the next few years, in a way that would lower their market value without affecting their face value, there would be reasons to worry. Ioannides agreed with Reis that accomplishing this in the Greek crisis was much harder, yet he wondered whether the profile of Portugal's payment obligations was so significantly different that it would be easier there. The payments it owed to the European Central Bank and the International Monetary Fund in 2015, for example, did seem substantial.

Jay Shambaugh was curious to know whether Reis regarded Portugal's experience as a macroeconomic policy success. He agreed that the shift away from nontraded goods and the fall in tradable unit labor costs have been impressive, but he wondered whether the transition needed to be as painful as it was. What if the European Central Bank had been more supportive as early as 2011 , or if there had been supportive fiscal policy across the eurozone as more of a single macroeconomic unit? Then rather than arguing over whether Portugal's austerity itself was bad one might have wound up with a better recovered euro area, excluding Germany, instead of an area down 6 percent GDP per capita.

Reis responded by addressing five issues that had been directly or indirectly raised. First, concerning long-run growth, he believed the prospects for the entire eurozone look dismal and the same must be said for Portugal. He considered the country to have had a macroeconomic success only insofar as it weathered an adjustment well. It is even doing a bit better than 
Italy, one of its comparator countries, which had no adjustment program. His point in the paper was not to say Portugal is now doing well in absolute terms and can be called a great success story, nor even, in response to Shambaugh's comment, that there have been no policy mistakes.

A second issue concerned the labor market. As in Italy and Spain, Reis said, in Portugal a large fraction of the population is accustomed to extremely protected labor markets that keep many workers from being fired under almost any circumstance. In response, the economy has ended up with a growing number of temporary contract workers. This problem is greatest in Portugal, where it was already evident almost 20 years ago. Of all new jobs created since 2000, 80 percent have been such temporary positions. As a result, somewhere between a third to half the labor forcedepending on estimates-is now employed through these flexible contracts. The resulting dual labor markets are not a good thing. In Portugal now, 50 percent of the labor force has very low productivity, which is partly why the total factor productivity levels in growth are so low. At the same time, it has the advantage that when a shock occurs and employment must adjust up or down it allows employers a lot of discretion.

A third issue concerned the puzzle of international exchange rates and their impact on balance of trade. Usually, while exchange rates move a lot, credit accounts do not. Currency unions like the eurozone's create a special situation, a kind of hyperconnected exchange rate. Starting around 2000, some of the current accounts, including Ireland's and Portugal's, went through massive swings with very large deficits, even with moderate CPI-based rate changes, and now we see credit accounts fall tremendously. So trade balances go up and down with fairly moderate real exchange rate changes, and this is true not only for Portugal.

In response to Davis's concern about the reliability of labor input measures, a fourth issue, Reis described Portugal's new tax-compliance measures. To increase its revenues, the country has adopted IMF-recommended measures, and consequently tax compliance has improved quite a bit, especially in retail and wholesale trade. For instance, shops not only need to receive invoices but their cash registers are electronically connected to the revenue service. The sales staff are even incentivized to use the system through government lottery prizes, including expensive cars. These approaches have been extremely effective, an example of applied behavioral economics. The other benefit is that reported wholesale and retail sales have risen massively. There had been tax evasion in the past, but now, with better reporting of output, the numbers show higher output per hour as well. 
Finally, Reis agreed with the point raised about immigration, that it has an important effect on employment and recovery. In addition to people leaving Portugal for work, the country has stopped receiving Eastern Europeans who left their home countries looking for jobs. Reis suspected that migration cannot explain all the upward movement of the employment rate, however. It is hard to measure this accurately, though, until the census has been taken. 